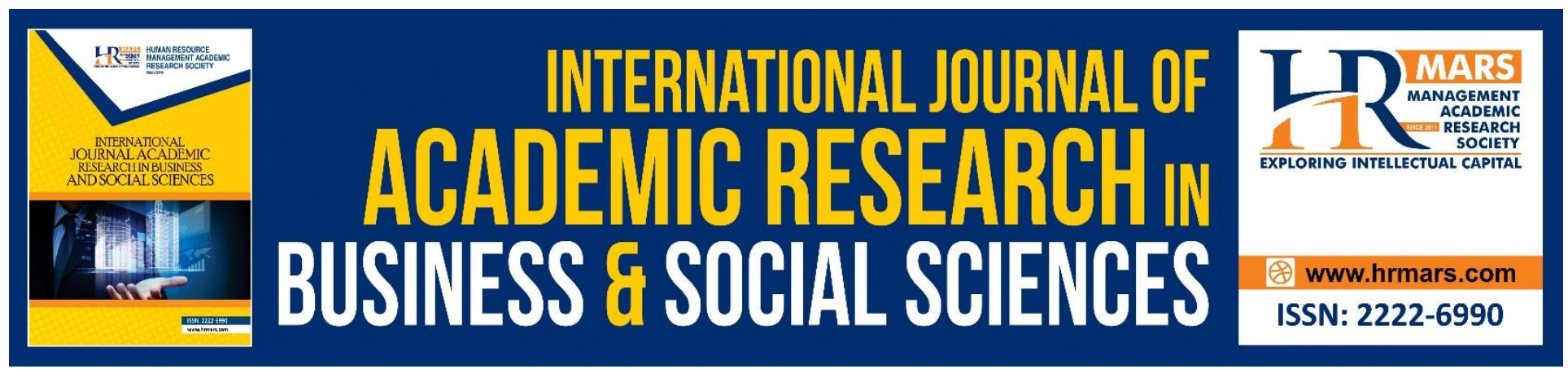

\title{
Physical Environment and Residents' Perception towards Tourism Impacts: A Case Study of Tioman Island
}

Norhafiza Md Sharif \& Ku 'Azam Tuan Lonik

To Link this Article: http://dx.doi.org/10.6007/IJARBSS/v10-i11/7948

DOI:10.6007/IJARBSS/v10-i11/7948

Received: 19 September 2020, Revised: 30 September 2020, Accepted: 16 October 2020

Published Online: 11 November 2020

In-Text Citation: (Sharif, \& Lonik, 2020)

To Cite this Article: Sharif, N. M., \& Lonik, K. A, T. (2020). Physical Environment and Residents' Perception Towards Tourism Impacts: A Case Study of Tioman Island. International Journal of Academic Research in Business and Social Sciences. 10(11), 215-228.

Copyright: (C) 2020 The Author(s)

Published by Human Resource Management Academic Research Society (www.hrmars.com)

This article is published under the Creative Commons Attribution (CC BY 4.0) license. Anyone may reproduce, distribute, translate and create derivative works of this article (for both commercial and non-commercial purposes), subject to full attribution to the original publication and authors. The full terms of this license may be seen

at: http://creativecommons.org/licences/by/4.0/legalcode

Vol. 10, No. 11, 2020, Pg. 215 - 228

http://hrmars.com/index.php/pages/detail/IJARBSS

JOURNAL HOMEPAGE

Full Terms \& Conditions of access and use can be found at http://hrmars.com/index.php/pages/detail/publication-ethics 


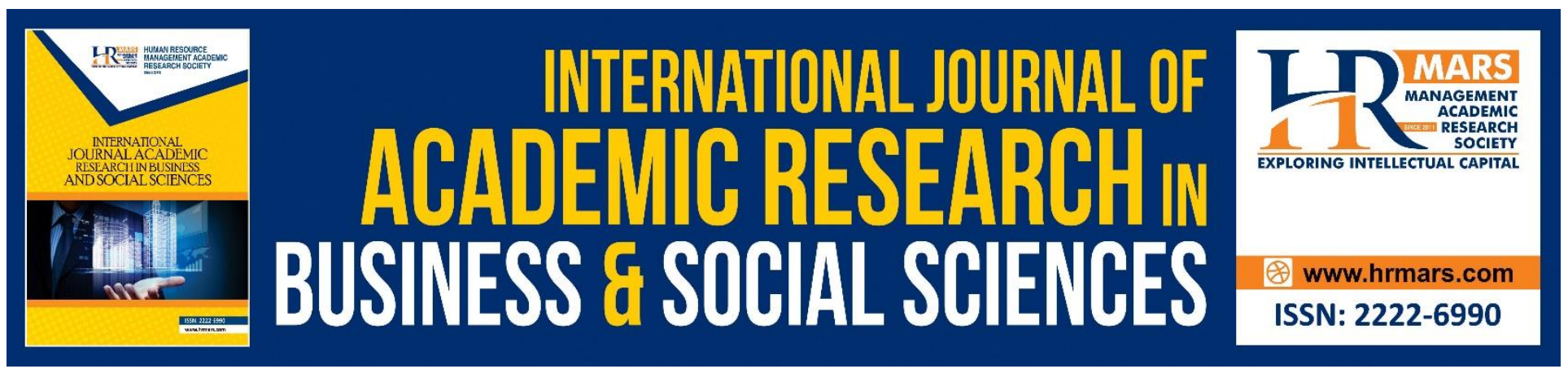

\title{
Physical Environment and Residents' Perception Towards Tourism Impacts: A Case Study of Tioman Island
}

\author{
Norhafiza Md Sharif' \& Ku 'Azam Tuan Lonik²
}

School of Distance Education, School of Distance Education, Universiti Sains Malaysia, Pulau Pinang, Malaysia ${ }^{1 \& 2}$

Email: norhafiza_mdsharif@usm.my

\begin{abstract}
Beautiful island environment can be an important asset for this country to attract tourists. However, the uncontrolled tourism activities can pose to the negative impacts on the natural environment. This article aimed to identify the perception of the resident on environmental impacts and their support towards tourism development. This study used quantitative methods to conduct questionnaire forms on 280 respondents who were residents of Tioman Island using a simple random sampling method. The collected data were analyzed using SPSS software, version 24 and analyzed using descriptive statistics (mean, percentage and standard deviation) and correlation pearson. The results showed that poor tourism development has contributed to the negative impact on marine life (mean=4.71). However, the tourism sector has also created environmental awareness among residents (mean=4.56). A strong positive relationship $(r=0.885, \rho<0.05)$ was found between the positive impact of the environment and residents support for the tourism sector. This study may provide useful information that could be used to plan the development of tourism, taking into account aspects of environmental assessment in the affected areas.

Keywords: Environmental Impacts, Island Tourism, Tourism Impacts, Resident Perception, Support Towards Tourism.

\section{Introduction}

The tourism industry has been identified as a major catalyst in the services sector. In 2014, the tourism industry in Malaysia recorded a foreign exchange earning of RM72 billion compared to RM56.5 billion in 2010, an increase of 27.4\% (Economic Planning Unit, 2015). This positive economic performance prompted Malaysia to make the tourism sector one of the main catalysts in the National Key Economic Area (NKEA) where it serves as a driver of economic activity for the Malaysians (Department of Information Malaysia, 2019).
\end{abstract}


INTERNATIONAL JOURNAL OF ACADEMIC RESEARCH IN BUSINESS AND SOCIAL SCIENCES Vol. 10, No. 11, 2020, E-ISSN: 2222-6990 @ 2020 HRMARS

Recognizing the great potential of the tourism sector, the government has sought the best alternative to increase tourism products in line with the developmental efforts of other countries in Southeast Asia. The existence of beautiful beaches and islands in Malaysia has the great potential to be one of the tourism products that can attract tourists to this country. In addition, CNN Travel (2017) also recognized three beaches in Malaysia in the list of 50 best beaches in the world namely Tanjung Rhu in Langkawi, Kedah (49th rank), Juara Beach in Tioman Island, Pahang (21st rank) and Pulau Perhentian Kecil, Terengganu (13th rank). Moreover, Malaysia is also listed as one of the 10 best destinations in the world that should be visited (Lonely Planet, 2017).

However, the uncontrolled influx of tourists is feared to affect the environmental capacity limit and consequently cause damage to the natural environment at the tourist destination (Sunlu 2003; Livadeas and Smith 2018; Taiminen 2019). In fact, poor tourism development has contributed many problems on the environment (Ozturk et al. 2015; Mohammed 2018; Mikayilov et al. 2019). More worryingly, the environmental damage that has occurred will take a long time to recover and consequently, affect the quality and experience of tourists in the areas affected (Bohm and Pfister 2011; GhulamRabbany et al. 2013; Asadzadeh and Mousavi 2017).

In this regard, this study aims to identify the environmental impact received by the residents as a result of tourism development, as well as to examine the relationship between environmental impact with resident support for the development of the tourism sector in Tioman Island.

This study could contribute to government planning in the development of the tourism sector. It is important to study the perception of the residents on the physical environmental impacts of the tourism sector to evaluate the positive and negative effects that have been received, and this is in line with the National Tourism Policy 2030 aimed at strengthening the commitment to achieve sustainable tourism. In addition, Research and Development (R\&D) needs to be enhanced to improve the quality of services and ensure the sustainability of the island's tourism sector.

\section{Study Area}

Tioman Island

Tioman Island is a mukim and an island in Rompin District, Pahang, Malaysia. It is located 32 kilometres (20 miles) off the east coast of the state, and is some 20 kilometres (12 miles) long and 12 kilometres (7.5 miles) wide (Rompin District \& Land Office, 2020). Tioman Island is the largest island in the archipelago of nine islands (Pulau Tioman, Pulau Tulai, Pulau Labas, Pulau Sepoi, Pulau Seri Buat, Pulau Tokong Bahara, Pulau Gut, Pulau Cebeh and Pulau Sembilang) forming the Tioman Island Marine Park. 
INTERNATIONAL JOURNAL OF ACADEMIC RESEARCH IN BUSINESS AND SOCIAL SCIENCES Vol. 10, No. 11, 2020, E-ISSN: 2222-6990 @ 2020 HRMARS

Figure 1: Map of Tioman Island, Pahang

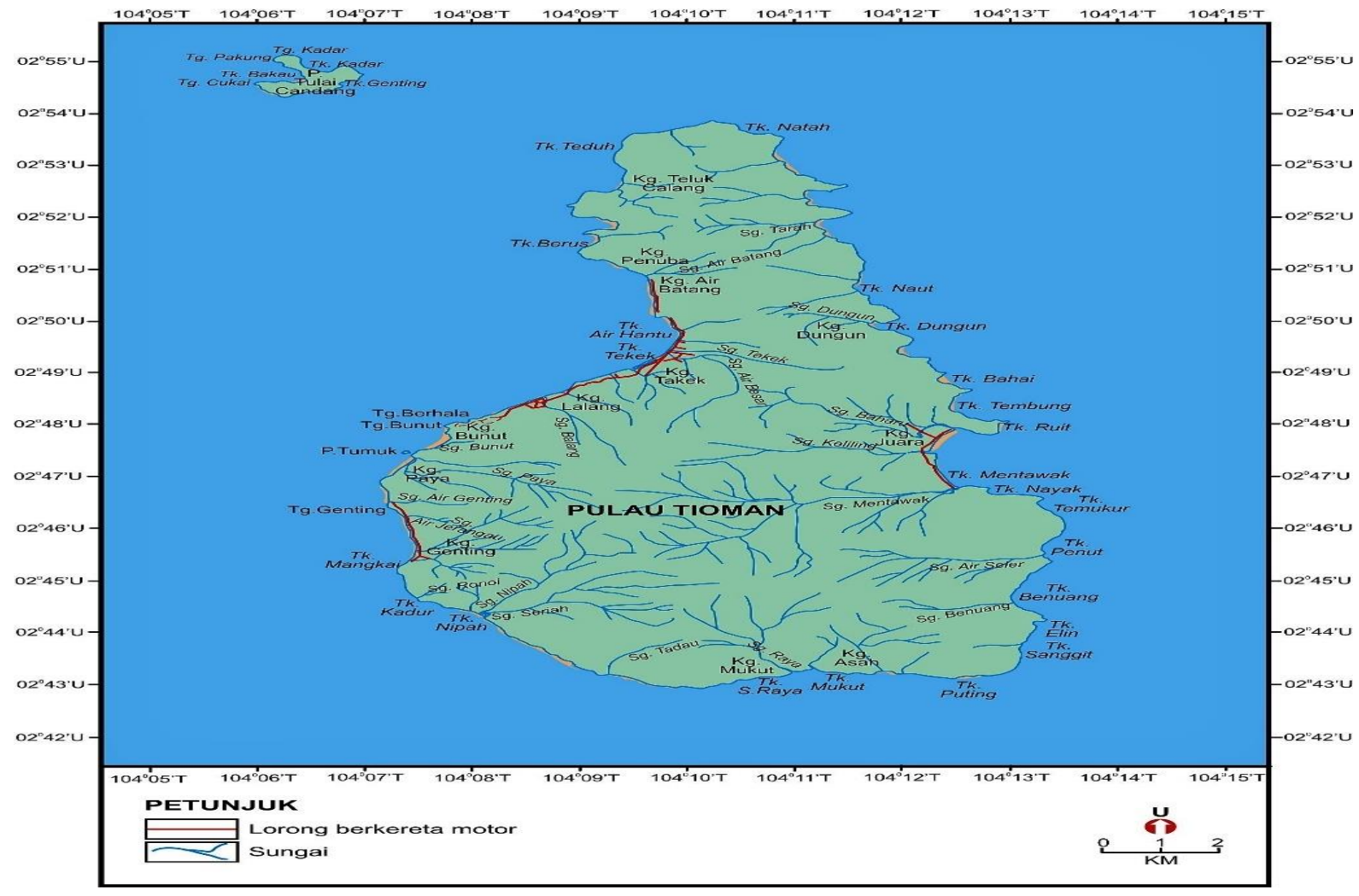

Source: Md Sharif (2017)

The island is approximately 32 nautical miles east of Tanjung Gemuk, Pahang and was gazetted as a Marine Park in 1994 under the Fisheries Act 1985 (Amendment 1993). In addition, five other islands namely Pulau Renggis, Pulau Tumok, Pulau Soyak, Pulau Tasu and Pulau Raja are also included within the boundaries of the park (Department of Marine Park Malaysia, 2020).

Tioman Island tourism products are nature-based covering the islands of the Marine Park and Wildlife Reserves (Figure 2). In terms of facilities, Tioman Island Marine Park provides a variety of interesting recreational activities such as snorkelling, diving, picnicking, camping, fishing, boating, swimming, jungle tracking and hill climbing, bird watching, wildlife observation and photography. 
INTERNATIONAL JOURNAL OF ACADEMIC RESEARCH IN BUSINESS AND SOCIAL SCIENCES Vol. 10, No. 11, 2020, E-ISSN: 2222-6990 @ 2020 HRMARS

Figure 2: The surroundings of Tioman Island, Pahang.
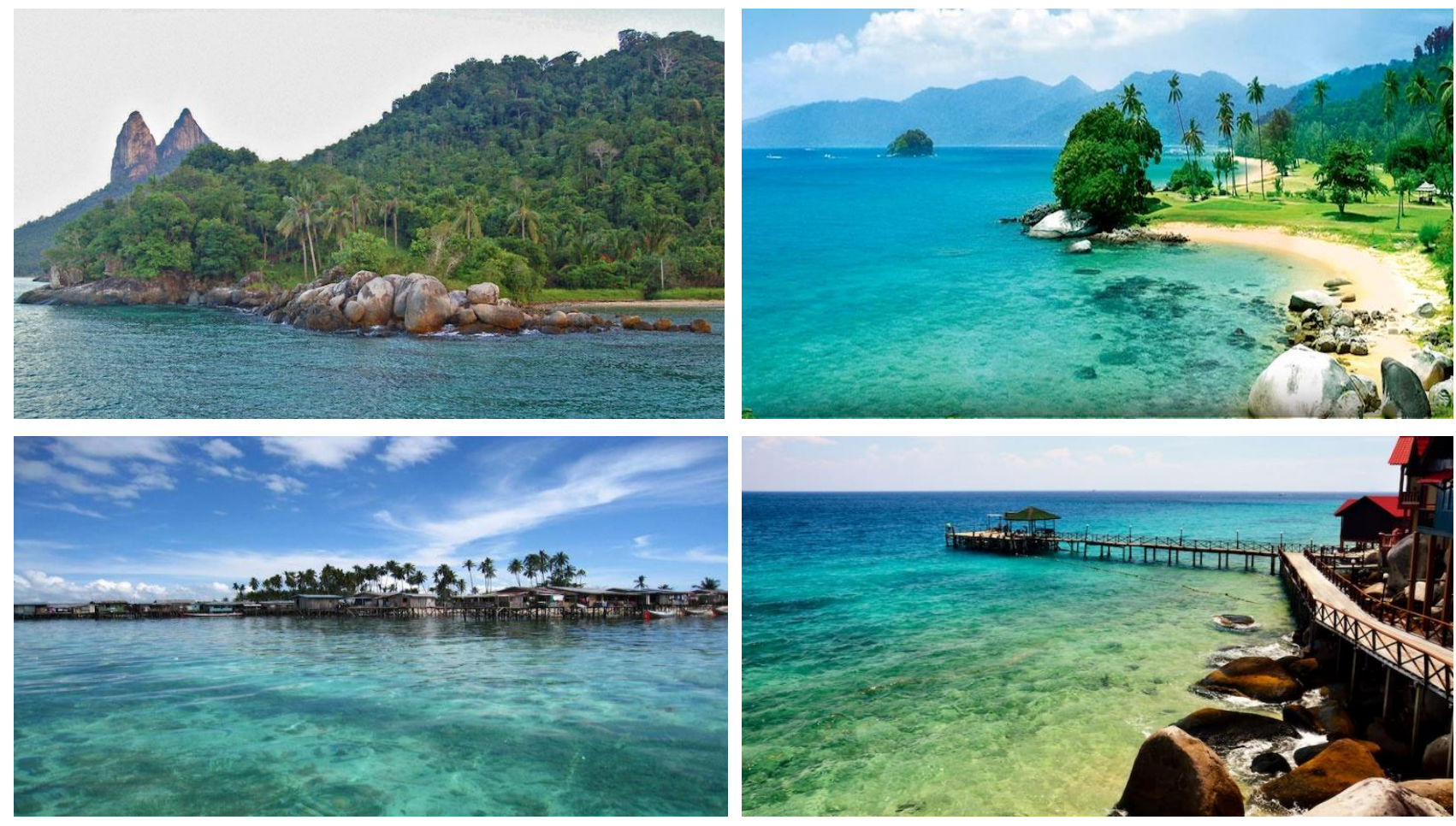

Source: Rompin District \& Land Office (2020).

\section{Literature Review \\ Negative Environmental Impacts}

Typically, the deterioration of the quality of the environment is often due to human activities and therefore disrupts the ecological balance (Kameda et al. 2011; Vennila et al. 2014; Ghorani-Azam et al. 2016; Appannagari 2017). The negative impacts from the tourism sector usually occur when the level of tourist use exceeds the capacity of the environment to cope with this use within the acceptable limits of change (Sunlu, 2003). Therefore, the development of uncontrolled tourism sector could pose a threat to natural areas around the world (Masa'deh et al. 2017).

Previous studies (Sunlu 2003; Yazdi 2007; Ghobadi and Verdian, 2016) have indicated that tourism development caused many problems to the environment, including the destruction of vegetation, water pollution in coastal areas and the destruction of the coastal landscape. In addition, the tourism industry has also affects water quality through the construction and maintenance of infrastructure for boat and recreational facilities (Reopanichkul, 2009). According to Hall (2002), ecosystems and natural habitats may suffer from damage to infrastructure, recreational boat activities and the cruise industry. Caric and Mackelworth (2014) found that recreational and boat activities could destroy the ocean ecosystem. The construction of new hotels and recreation centers has led to an increase in wastewater and consequently increased the destruction of marine vegetation while reducing the diversity of fauna and oxygen supply (Yazdi and Saghayei, 2007). Therefore, Piazzi et al. (2005) and Antolic et al. (2008) expressed their concern for two species of algae, namely Caulerpa taxifolia and Caulerpa racemose that could be endangered by disruption of the marine ecosystem. 
INTERNATIONAL JOURNAL OF ACADEMIC RESEARCH IN BUSINESS AND SOCIAL SCIENCES Vol. 10, No. 11, 2020, E-ISSN: 2222-6990 @ 2020 HRMARS

Additionally, uncontrolled waste disposal also contributes to environmental problems as a result of tourism activities (Chen et al. 2017). In fact, the problem of sewage treatment system management has also led to the release of high levels of nitrogen and phosphorus thus affecting the life of coral reefs in the oceans (Burke et al. 2002). Also, previous studies (Wang et al. 2018; Zajchowski et al. 2019; Zhou et al. 2018; Yan et al. 2019) have found that tourism activities also contribute to air pollution problems. Besides, Xuchao et al. (2010) and Tovar and Lockwood (2008) added that the tourism activities have contributed to the effects of air pollution through the carbon dioxide $\left(\mathrm{CO}^{2}\right)$ emission and therefore, causes environmental degradation (Wu and Shi 2011; Katircioglu et al. 2014; Wang et al. 2016; Tang et al. 2018).

\section{Positive Environmental Impacts}

In terms of the positive impact, tourism development also has the potential to increase public appreciation and awareness of the environment. Typically, environmental awareness is fundamental to a change in the behaviour of a person responsible for protecting the environment (Mobley et al. 2010; GhulamRabbany et al. 2013; Asadzadeh and Mousavi 2017; Lee et al. 2017; Queiros and Mearns 2018). According to Yuxi and Linsheng (2017), understanding of the importance of the environment will influence the behaviour and interaction between tourists and the environment (Gay 2011; Snyman and Bricker 2019).

In addition, tourism development also focuses on important environmental issues to stimulate initiatives that can conserve and improve the quality of the environment (Tambovceva 2010; Nair and Thomas 2013; UNEP 2015). Therefore, the tourism sector also takes into account issues related to biodiversity, endangered species and the impact of human activities on the environment (Nair and Thomas 2013; UNEP 2015; Convention on Biological Diversity 2019).

\section{Residents' Perception of the Impacts of Tourism Development}

The growing tourism sector is seen to be contributing to many positive and negative impacts on the economy, environment and social life (Yoon et al. 2001). Residents' perceptions towards tourism impacts also change over time. Williams and Lawson (2001) and Andriotis (2004) argue that perceptions and attitudes of society vary based on the accepted effects. In general, the impacts of tourism development received by the local community will affect their perception and support towards the tourism sector (Brida et al. 2011; Nunkoo and and Gursoy 2012; Stylidis et al. 2014; Garcia et al. 2015).

\section{Methodology \\ Sampling Methods}

The data for this study were obtained through the distribution of questionnaire forms conducted on 280 respondents residing in Tioman Island using a simple random sampling technique. The data collected through the questionnaire consists of two (2) main parts:

a) Socio-demographic profile of the resident Questions regarding the characteristics of the socio-demographic profile of the resident include gender, age, marital status, educational level, employment sector, monthly income and resident status.

b) Environmental impacts of the tourism sector 
INTERNATIONAL JOURNAL OF ACADEMIC RESEARCH IN BUSINESS AND SOCIAL SCIENCES

Vol. 10, No. 11, 2020, E-ISSN: 2222-6990 @ 2020 HRMARS

In this section, a total of 15 questions were prepared based on 5 likert scales to measure the perceptions of the environmental impacts on the tourism sector. There are two parts of environmental impacts, namely:

a. Negative environmental impacts which consisted of 10 questions.

b. Positive environmental impacts which consisted of 5 questions.

\section{Data Analysis}

In this study, data analysis was performed using Statistical Package for the Social Sciences (SPSS) software system, version 24 . The data collected in this study were analysed using descriptive analysis (mean, percentage and standard deviation) and correlation pearson.

\section{Findings and Discussions}

\section{Socio-demographic Profiles}

Results in Table 1 showed that the majority of the respondents were male (61.4\%) and the rest $38.6 \%$ were female. Most of the respondents (51.1\%) were aged between 25 until 44 years old, followed by respondents aged 45 until 54 years old (33.6\%), 55 until 64 years old (10.4\%) and aged 65 years old and above (5\%). The majority of respondents (91.8\%) were married, while $5.4 \%$ were widows and only $2.9 \%$ were widowers. Most of the Respondents received education up to secondary school level (62.5\%), primary school level (30.0\%) and the rest $7.5 \%$ had no formal education.

In terms of occupation, most respondents were involved in the accommodation sectors such as chalets or resorts (37.5\%), food and beverages (17.5\%), boats and equipment for water activities services $(10.0 \%)$, government sectors $(9.3 \%)$, retail stores $(8.6 \%)$, vehicles rental services $(6.4 \%)$, souvenir shops (6.1\%), laundry services (2.5\%), reflexology massage services $(1.4 \%)$ and batik painting $(0.7 \%)$. As Tioman Island is one of the most popular tourist destinations, respondents were mostly involved in tourism-based jobs. The results also found that most of the respondents $(41.2 \%)$ received an estimated monthly income of RM1001-RM2000 (36.4\%), RM2001-RM4000 (30.4\%), followed by RM4001-RM5000 (17.1\%) and RM5001 and above (5\%). All respondents in this study area were Malays who are the majority of the population in Tioman Island.

The study also revealed that the majority of the respondents were native residents and constituted $87.5 \%$, while $12.5 \%$ were non-native residents. Most of the respondents who were non-native residents comprised of the government servants working in government departments located in Kampung Tekek, Tioman Island and people who moved from the mainland to Tioman Island after marriage as well as those seeking for job opportunities in Tioman Island.

\section{Residents' Perceptions of the Environmental Impacts of the Tourism Sector Perception of Negative Environmental Impacts}

The environmental impacts of the tourism sector of Tioman Island can be seen in Table 1. In terms of the negative impacts on the environment, the residents expressed the highest concern about the problem of "marine life affected by tourism activity" (mean=4.71). This was followed by residents' concern about the "erosion at the beach" (mean=4.64) as well as the "changing landscape of the island area" (mean=4.63). In addition, residents also found that "waste management is not well managed" (mean=4.62) and similarly "the drainage system of chalets is not well managed" 
INTERNATIONAL JOURNAL OF ACADEMIC RESEARCH IN BUSINESS AND SOCIAL SCIENCES Vol. 10, No. 11, 2020, E-ISSN: 2222-6990 @ 2020 HRMARS

(mean=4.55). Besides, residents also believe that tourism development can cause "soil pollution" (mean=4.46), "affecting flora and fauna habitat" (mean=4.42), "noise pollution" (mean=4.41), followed by their concerned of "air pollution" (mean=4.39), and raised issues of "landslides in the hills as a result of tourism development" (mean=4.31).

Overall, the result showed that most residents agree that a poorly regulated tourism sector may cause marine life to be affected by tourism activities. This finding is supported by previous studies (Papali Yazdi and Saghayei 2007; Antolic et al. 2008; Reopanichkul 2009; Caric and Mackelworth 2014; Mohammed 2018; Rashid Khan et al. 2020) which found that tourism activities affect the ecosystems and marine life.

If the marine ecosystem is threatened, it will also have an adverse impact on other ecosystems and will result in deterioration of flora and fauna which has been a major attraction for tourists coming to Tioman Island. Moreover, the affected marine life will also affect the number of fish caught by the fishermen on the island.

Table 1: Environmental impacts of the tourism sector on Tioman Island

\begin{tabular}{|c|c|c|c|c|c|c|c|}
\hline \multirow[t]{2}{*}{ Environmental impacts } & \multicolumn{5}{|c|}{5 likert scales (\%) } & \multirow[t]{2}{*}{ Mean } & \multirow{2}{*}{$\begin{array}{l}\text { Standard } \\
\text { deviation }\end{array}$} \\
\hline & 1 & 2 & 3 & 4 & 5 & & \\
\hline \multicolumn{8}{|l|}{ Negative environmental impacts } \\
\hline Occurrence of beach erosion. & 0.7 & 4.3 & 2.9 & 14.3 & 77.9 & 4.64 & 0.794 \\
\hline Marine life is affected by tourism activities. & 0.7 & 2.5 & - & 18.2 & 78.6 & 4.71 & 0.664 \\
\hline $\begin{array}{l}\text { The sewerage system of the chalet was not } \\
\text { well managed. }\end{array}$ & 3.6 & 3.2 & - & 20.7 & 72.5 & 4.55 & 0.933 \\
\hline $\begin{array}{l}\text { There was a landslide in the hills as a result } \\
\text { of tourism development. }\end{array}$ & 4.3 & 9.6 & 3.2 & 15.7 & 67.1 & 4.31 & 1.174 \\
\hline $\begin{array}{l}\text { Affect the flora and fauna habitat of forest } \\
\text { areas. }\end{array}$ & 3.2 & 8.2 & 4.6 & 10.4 & 73.6 & 4.42 & 1.10485 \\
\hline Waste management is not well managed. & 1.8 & 3.2 & - & 20.7 & 74.3 & 4.62 & 0.802 \\
\hline Noise pollution. & 2.5 & 3.6 & & 36.4 & 57.5 & 4.41 & 0.872 \\
\hline Air pollution. & 1.8 & 3.2 & 1.8 & 40.4 & 52.9 & 4.39 & 0.826 \\
\hline $\begin{array}{l}\text { The landscape of the island's surroundings } \\
\text { is changing. }\end{array}$ & 1.1 & 2.5 & 2.1 & 20.0 & 74.3 & 4.63 & 0.744 \\
\hline Soil pollution. & 1.8 & 2.5 & 3.2 & 32.5 & 60.0 & 4.46 & 0.824 \\
\hline \multicolumn{8}{|l|}{ Positive environmental impacts } \\
\hline $\begin{array}{l}\text { Increase environmental awareness among } \\
\text { residents. }\end{array}$ & - & 1.8 & 1.8 & 35.0 & 61.4 & 4.56 & 0.624 \\
\hline $\begin{array}{l}\text { Increase monitoring efforts from } \\
\text { environmental authorities. }\end{array}$ & 0.4 & 2.5 & .7 & 35.7 & 60.7 & 4.53 & 0.676 \\
\hline Leading to environmental protection. & - & 2.5 & 2.9 & 34.3 & 60.4 & 4.52 & 0.676 \\
\hline $\begin{array}{l}\text { It should take into account the } \\
\text { environmental aspects of sustainability. }\end{array}$ & - & 1.1 & 2.9 & 36.1 & 60.0 & 4.55 & 0.608 \\
\hline
\end{tabular}


INTERNATIONAL JOURNAL OF ACADEMIC RESEARCH IN BUSINESS AND SOCIAL SCIENCES Vol. 10, No. 11, 2020, E-ISSN: 2222-6990 @ 2020 HRMARS

\begin{tabular}{|l|l|l|l|l|l|l|l|}
\hline $\begin{array}{l}\text { Contributed to } \\
\text { preservation and restoration of the } \\
\text { environment. }\end{array}$ & - & 3.6 & 1.4 & 35.4 & 59.6 & 4.51 & 0.703 \\
\hline
\end{tabular}

Note: $1=$ strongly disagree, $2=$ disagree, $3=$ neutral, $4=$ agree, $5=$ strongly agree

\section{Perception of Positive Environmental Impacts}

In terms of the perceptions of positive impacts, the residents of Tioman Island are largely convinced that the tourism sector can "increase environmental awareness among residents" (mean=4.56). In addition, the residents were aware that tourism development "must take into account of the environmental aspects" (mean=4.55) and proposed to "increase monitoring efforts from environmental authorities" (mean=4.53) as well as their believe that good effort would "lead to environmental protection" (mean=4.52) and realized that the "tourism sector would contribute to the preservation and restoration of the environment" (mean=4.51).

Therefore it could be summarized that most residents tend to agree with the statement that the tourism sector has created environmental awareness among residents. This finding is line with the some studies (GhulamRabbany et al. 2013; Lee et al. 2017; Queiros and Mearns 2018; Snyman and Bricker 2019) which indicated that tourism sector management needs to raise the level of environmental awareness in the society.

\section{Environmental Impacts and Residents' Support towards the Tourism Sector Development}

The results of the pearson correlation analysis shown in Table 2 indicate that there is a moderate positive relationship $(r=0.555, \rho<0.05)$ with a significant correlation between the negative environmental impacts and residents' support towards tourism sector. On the other hand, there was a strong positive relationship $(r=0.885, \rho<0.05)$ with a significant correlation between the positive environmental impacts and residents' support for the tourism sector.

Table 2: Correlation analysis between environmental impacts and residents' support for the environment.

\begin{tabular}{|l|l|c|c|}
\hline \multicolumn{2}{|c|}{} & $\begin{array}{c}\text { Negative environmental } \\
\text { impacts }\end{array}$ & $\begin{array}{c}\text { Positive environmental } \\
\text { impacts }\end{array}$ \\
\hline $\begin{array}{l}\text { Support for the } \\
\text { tourism sector }\end{array}$ & Korelasi Pearson & 0.555 & 0.885 \\
\cline { 2 - 4 } & Sig. (2-tailed) & 0.000 & 0.000 \\
\cline { 2 - 4 } & $\mathrm{N}$ & 280 & 280 \\
\hline
\end{tabular}

Correlation is significant at the 0.01 level (2-tailed).

This means that the positive impacts of the environment has a stronger positive relationship with residents support for the tourism sector. This indicates that the higher the residents' acceptance of positive impacts, the higher their support for the tourism sector. As such, the perception of the residents on the negative environmental impacts is weakly related to the support of the residents in the tourism sector. These results have implications that residents who are aware of the environmental impacts are likely to have high support for tourism development on Tioman Island. 
INTERNATIONAL JOURNAL OF ACADEMIC RESEARCH IN BUSINESS AND SOCIAL SCIENCES Vol. 10, No. 11, 2020, E-ISSN: 2222-6990 @ 2020 HRMARS

The results of this study also summarize that residents receiving positive impacts from the tourism sector are more likely to support and engage in the sector, which is similar to what was observed from previous studies (Aref et al. 2009; Breugel, 2013; Brida et al. 2011; Garcia et al. 2005; Nunkoo and Ramkissoon 2011; Stylidis et al. 2014). This means if the resident believes that tourism creates more benefits than costs, so they tend to support the tourism sector. In other words, if they believe that tourism brings in more costs than benefits, then they are unlikely to support tourism development. This statement is in line with the goal of developing a tourism industry for a community that is to maximize the positive impacts and minimize negative impacts.

\section{Conclusion}

To sum up, this study involved 280 respondents in Tioman Island with a majority being male, aged 25 to 44 years, married, an educational level up to secondary school, working in chalets/resorts, receiving a monthly income of RM1001 to RM2000 and native residents of Tioman Island.

In terms of perceptions on the negative environmental impacts of the tourism sector on Tioman Island, the results conclude that most residents agreed that the poorly regulated tourism sector could cause marine life to be affected by tourism activities. However, in terms of their perceptions of the positive environmental impacts, it was observed that developments of the tourism sector have raised environmental awareness among residents.

This study concludes that there is a strong positive relationship between residents' perceptions of positive environmental impacts and their support for the tourism sector on Tioman Island. Therefore, it is clear that every impact of tourism development received by the local community will affect the perception and support of the resident towards the tourism sector. Basically, a common theory shared by the authors of studies about residents' perceptions is the social exchange theory (Harrill, 2004). It offers a framework for evaluating why an individual would participate in the exchange. The social exchange framework was developed in the 1950s and early 1960s from the work of sociologists Homans (1958); Emerson (1962) and Blau (1964), and the work of social psychologists Thibaut and Kelley (1959). Using social exchange theory, individual's attitudes towards tourism will be influenced by their evaluation of consequential outcomes in the community (Andereck et al., 2005). This means that an individual who receives costs and benefits related to the tourism development that tend to improve their quality of life are more likely to have a positive perception towards tourism development. On the other hand, individuals who perceive the disadvantages of tourism development, will oppose the sector. In this study, it can be concluded that the residents understand that the tourism sector could strengthen the national economy through the influx of tourists, but they also want natural resources to be protected. Therefore, resident' perceptions of the tourism sector are important because they are the group that will benefit from the development as well as become one of the key stakeholders in determining support for the tourism sector.

This study also shows that residents of the island are always alert to any impact on humans and the environment as a result of development. This is to ensure that each of these effects does not threaten the equilibrium of the ecosystem in the components of the earth's system. It is important to maintain the ecology and diversity of life in order to achieve sustainable development goals. To ensure that the island's ecosystem is maintained, everyone including governments, private sector, NGOs, tourists 
INTERNATIONAL JOURNAL OF ACADEMIC RESEARCH IN BUSINESS AND SOCIAL SCIENCES Vol. 10, No. 11, 2020, E-ISSN: 2222-6990 @ 2020 HRMARS

and residents should be aware of the importance of protecting the environment so that it is not affected by irresponsible and unregulated activities. These methods are important to ensure the earth's ecosystem is maintained while the next generation can use this environment to survive for their future.

\section{References}

Andereck, K. L., Valentine, K. M., Knopf, R. C., \& Vogt, C. A. (2005). Residents' Perceptions of Community Tourism Impacts. Annals of Tourism Research, 32(4), 1056-1076.

Andriotis, K., \& Vaughan, R.D. (2003). Urban Residents Attitudes toward Tourism Development: The Case of Crete. Journal of Travel Research, 42(2), 172-185

Antolic, B., Zuljevic, A., Despalatovic, M., Grubelic., \& Cvitkovic, I. (2008). Impact of the invasive green alga Caulerpa racemosa var. cylindracea on the epiphytic macroalgal assemblage of Posidonia oceanica seagrass rhizomes in the Adriatic Sea. Nova Hedwigia, 86(1-2), 155-167.

Appannagari, R. R. (2017). Environmental Pollution Causes and Consequences: A Study. North Asian International Research Journal of Social Science \& Humanities, 3(8), 151-161.

Aref, F., Gill, S. S., \& Redzuan, M. (2009). Community perceptions toward economic andcenvironmental impacts of tourism on local communities. Asian Social Science, 5(7), $130-$ 137.

Asadzadeh, A., \& Mousavi M. S. S. (2017). The Role of Tourism on the Environment and its Governing Law. Electronic Journal of Biology, 13(2), 152-158.

Bohm, G., \& Pfister, H. R. (2011). Tourism in the face of environmental risks: sunbathing under the ozone hole, and strolling through polluted air. Scandinavian Journal of Hospitality and Tourism, 11(3), 250-267.

Brida, J. G., Disegna, M., \& Osti, L. (2011). Residents' Perceptions of Tourism Impacts and Attitudes Towards Tourism Policies in a Small Mountain Community. Benchmarking. An International Journal, 18(3), 359-385.

Burke, L. M., Spalding, M., \& Selig, E. (2002). Reefs at risk in southeast Asia. Washington, D.C: World Resources Institute-Kogan Page.

Caric, H., \& Mackelworth, P. (2014). Cruise tourism environmental impacts-The perspective from the Adriatic Sea. Ocean \& Coastal Management, 102, 350-363.

Cavus, S., \& Tanrisevdi, A. (2003). Residents' Attitudes toward Tourism Development: A Case Study in Kusadasi, Turkey. Tour. Anal, 7(3-4), 259-269.

Chen, J. S. (2015). Tourism Stakeholders Attitudes Toward Sustainable Development: A Case in the Arctic. Journal of Retailing and Consumer Services, 22(1), 225-230.

CNN Travel. (2017). 10 Best Islands for a Malaysia Holiday. Retrieved from http://edition.cnn.com/travel/article/malaysia-best-islands/index.html. Accessed at 24 Mei 2020.

Convention on Biological Diversity. (2020). Retrieved from https://www.cbd.int/convention/text/. Accessed on 14 August 2020).

Department of Information Malaysia. (2019). Retrieved from http:// www.penerangan.gov.my Accessed on 10 January 2020.

Department of Marine Park Malaysia. (2020). Taman Laut Pahang. Retrieved from http://marinepark.dof.gov.my/ptl_pahang.html?uweb=\&lang=en. Accessed on 22 September 2020. 
INTERNATIONAL JOURNAL OF ACADEMIC RESEARCH IN BUSINESS AND SOCIAL SCIENCES Vol. 10, No. 11, 2020, E-ISSN: 2222-6990 @ 2020 HRMARS

Economic Planning Unit. (2015). Ucapan Yab Perdana Menteri Di Dewan Rakyat. Rancangan Malaysia kesebelas (2015-2020). Retrieved from https://www.pmo.gov.my/dokumenattached/speech/files/RMK11_Ucapan.pdf. Accessed on 24 September 2020.

Garcia, F. A., Vazquez, A. B., \& Macias, R. C. (2015). Resident's Attitudes Towards The Impacts of Tourism. Tourism Management Perspectives, 13, 33-40.

Ghobadi, G. J., \& Verdian, M. S. (2016). The Environmental Effects of Tourism Development in Noushahr. Open Journal of Ecology, 6, 529-536.

GhulamRabbany, M., Afrin, S., Rahman, A., Islam, F., \& Hoque, F. (2013). Environmental Effects of Tourism. American Journal of Environment, Energy and Power Research, 1(7), 117-130.

Hall, M. C. (2002). Trends in Ocean and Coastal Tourism: The End of The Last Frontier?. Ocean \& Coastal Management, 44(9), 601-618.

Harrill, R. (2004) Residents' attitudes toward tourism development: a literature review with implications for tourism planning. Journal of Planning Literature, 18, 251-266.

Kameda, T., Akiyama, A., Toriba, A., Tang, N., \& Hayakawa, K. (2011). Atmospheric formation of hydroxynitropyrenes from a photochemical reaction of particle-associated 1nitropyrene. Environ Sci Technol, 45(8), 3325-3332.

Katircioglu, S. (2009). Revisiting the tourism-led-growth hypothesis for Turkey using the bounds test and Johansen approach for cointegration. Tour Management, 30(1), 17-20.

Lee, H. Y., Bonn, M. A., \& Reid, E. L. (2017). Differences in tourist ethical judgment and responsible tourism intention: An ethical scenario approach. Tourism Management, 60, 298-307.

Livadeas, C., Smith, N. (2018). Asia's paradise islands face closure as they struggle to balance booming tourism with preservation, The Telegraph. Retrieved from https://www.telegraph.co.uk/news/2018/04/01/island-made-famousleonardo-dicapriofilm- beach-closes-strain/. Accessed on 24 June 2020.

Lonely Planet. (2017). Best in Asia. The Asian Destination you Should see now. Retrieved from https://www.lonelyplanet.com/best-in-asia. Accessed on 2 June 2020.

Sharif, M. N. (2017). Pelancongan Pulau dan Pembangunan Sosioekonomi Pengusaha Tempatan. PhD dissertation, School of Distance Education, Universiti Sains Malaysia.

Mikayilov, J. I., Mukhtarov, S., Mammadov, J., \& Azizov, M. (2019). Re-evaluating the environmental impacts of tourism: does EKC exist? Environmental Science and Pollution Research, 26, 1938919402

Mobley, C., Vagias, W. M., \& DeWard, S. L. (2010). Exploring additional determinants of environmentally responsible behavior: The influence of environmental literature and environmental attitudes. Environment and Behavior, 42(4), 420-447.

Mohammed, K. N. (2018). An Assessment of Tourism's Environmental Impact on the Lake osomtwe Basin. International Journal of Hospitality \& Tourism Administration, 19(3), 259- 288.

Nair, P. K., \& Thomas, T. K. (2013). Sustainable Tourism in Malaysia. Policies and Practices. Mondes du Tourisme, (8), 60-69.

Nunkoo, R., \& Ramkissoon, H. (2012). Power, Trust, Social Exchange and Community Support. Annals of Tourism Research, 39(2), 997-1023.

Nunkoo, R., \& Gursoy, D. (2012). Residents' support for tourism: An identity perspective. Ann. Tour. Res, 39(1), 243-268. 
INTERNATIONAL JOURNAL OF ACADEMIC RESEARCH IN BUSINESS AND SOCIAL SCIENCES Vol. 10, No. 11, 2020, E-ISSN: 2222-6990 @ 2020 HRMARS

Ozturk, I., Al-Mulali, U., \& Saboori, B. (2015). Investigating the environmental Kuznets curve hypothesis: the role of tourism and ecological footprint. Environ Sci Pollut Res, 23(2), 19161928.

Piazzi, L., Meinesz, A., Verlaque, M., Akcali, B., Antolic, B., \& Argyrou, M. (2005). Invasion of Caulerpa racemosa var. cylindracea (Caulerpales, Chlorophyta) in the Mediterranean Sea: an assessment of the spread. Cryptogam. Algol, 26(2), 189-202.

Reopanichkul, P. (2009). The Effect of Tourism on Water Quality and Coral Reef Communities. PhD dissertation, University of the Sunshine Coast Queensland, Australia.

Rompin District \& Land Office. (2020). Tioman Island. Retrieved from http://pdtrompin.pahang.gov.my/en/info-daerah/tempat-menarik/pulau-tioman. Accessed on 28 October 2020.

Queiros, D., \& Mearns, K. (2018). Khanyayo village and Mkhambathi Nature Reserve, South Africa: a pragmatic qualitative investigation into attitudes towards a protected area. Journal of Sustainable Tourism, 27(6), 750-772.

Snyman, S., \& Bricker, K. S. (2019). Living on the edge: benefit sharing from protected area tourism. Journal of Sustainable Tourism, 27(6), 705-719.

Stylidis, D., Biran, A., Sit, J., \& Szivas, E. M. (2014). Residents' Support for Tourism Development: The Role of Residents' Place Image and Perceived Tourism Impacts. Tourism Management, 45, 260-274.

Sunlu, U. (2003). Environmental impacts of tourism. In: Camarda D. (ed.), Grassini L. (ed.). Local resources and global trades: Environments and agriculture in the Mediterranean region (pp. 263-270) Bari. CIHEAM.

Taiminen, S. (2018). The negative impacts of over tourism on tourism destination from environmental and socio-cultural perspectives. Degree Thesis, Universitat Autònoma de Barcelona.

Tambovceva, T. (2010). Environmental Management Opportunities in Tourism Industry. 6th International Scientific Conference. 13-14 May 2010. Vilnius, Lithuania.

Tang, Z., Bai, S., Shi, C., Liu, L., \& Li, X. (2018). Tourism-Related CO2 Emission and Its Decoupling Effects in China: A Spatiotemporal Perspective. Advances in Meteorology. https://doi.org/10.1155/2018/1473184

Tovar, C., \& Lockwood, M. (2008). Social impacts of tourism: An Australian regional case study. International journal of tourism research, 10(4), 365-378.

UNEP. (2015). Tourism Supporting Biodiversity: A Manual on applying the CBD Guidelines on Biodiversity and Tourism Development. Secretariat of the Convention on Biological Diversity. Retrieved from https://www.cbd.int/tourism/doc/tourism-manual-2015-en.pdf. Accessed on 20 July 2020.

Vennila, A., Sheela, I., \& Purushothaman, C. S. (2014). Human induced ecological imbalance effect on ocean life. J. Environmental Social Sci, 1(21), 1-4.

Wang, K., Xiao, Y., Li, Z. M., \& Liu, H. L. (2016). Decomposition of China's tourism carbon emissions: Based on LMDI method. Tour. Sci. 30, 13-27.

Wang, L., Fang, B., \& Law, R. (2018). Effect of air quality in the place of origin on outbound tourism demand: disposable income as a moderator. Tourism Management, 68, 152-161.

Williams, J., \& Lawson, R. (2001). Community issues and resident opinions of tourism. Annals of Tourism Research, 28(2), 269-290. 
INTERNATIONAL JOURNAL OF ACADEMIC RESEARCH IN BUSINESS AND SOCIAL SCIENCES Vol. 10, No. 11, 2020, E-ISSN: 2222-6990 @ 2020 HRMARS

Wu, P., \& Shi, P. H. (2011). An estimation of energy consumption and $\mathrm{CO}^{2}$ emissions in tourism sector of China. J. Geogr. Sci, 21, 733-745

Xuchao, W., Priyadarsini, R., \& Eang, L. S. (2010). Benchmarking energy use and greenhouse gas emissions in Singapore's hotel industry. Energy Policy, 38(8), 4520- 4527.

Yoon, Y., Gursoy, D., \& Chen, J. S. (2001). Validating a tourism development theory with structure eqution modeling. Tourism Management, 22(4), 363-372.

Yuxi, Z., \& Linsheng, Z. (2017). Impact of Tourist Environmental Awareness on Environmental Friendly Behaviors: A Case Study from Qinghai Lake, China. Journal of Resources and Ecology, 8(5), 502-513. 